\title{
Trump, Trade and National Security: Will Federal Courts Rein in the President?*
}

\author{
Stuart S. Malawer**
}

President Trump has, for the first time in the US trade history, aggressively redefined the US trade policy as a supporting actor in the US national security policy. His presidential actions have involved a broad array of legislation, such as trade sanctions and export controls. Most astonishing is that President Trump has imposed trade restrictions by relying upon unilateral findings of national security risks or the existence of national emergencies. We are now at a point where federal courts in the US have been asked to review the validity of presidential trade actions, specifically the central legality of the broad delegation of congressional trade authority over the last 75 years. I predict that the federal courts will uphold the separation of powers in the face of the outrageous and unprecedented onslaught of presidential tariff and trade actions by a president relying upon dubious claims of national security and national emergency.

* An abbreviated and earlier version of this article titled, Stuart Malawer, Three Trade Cases to Rein in Trump's Tariffs was printed as an Op-Ed in the Richmond Times-Dispatch (June 16, 2019), available at https://www.richmond.com/opinion/their-opinion/stuart-s-malawer-column-threetrade-cases-to-rein-in/article_2ff934c9-ob78-5e89-9e82-fbb05913bc42.html. All the websites cited in this article were last visited on August 3, 2019.

** Distinguished Service Professor of Law and International Trade at George Mason's University's Schar School of Policy and Government. J.D. (Cornell), M.A./Ph.D. (UPenn), Diploma (Hague Academy of International Law). Additional legal studies at Harvard Law School and Oxford University (St. Peter's College). He is the author of WTO LAW, LITIGATION \& POLICY (Hein 2007) and U.S. National SECURITY LAW (Hein 2009). He is a recent gubernatorial appointee to the new Advisory Committee on International Trade (Virginia Economic Development Partnership). The author may be contacted at: StuartMalawer@msn.com; http://www.GlobalTradeRelations. net; http://www.US-Global-Law.net/Address: 3351 Fairfax Dr., MS 331, Arlington, Virginia 22201 USA. 
Keywords: National Security, National Emergency, Section 232, Separation of Powers, Non-delegation of Legislative Function, Trade Policy, Federal Litigation and Trade, WTO Litigation

\section{President Trump's Aggressive Trade Actions}

Ever since President Trump's inauguration, I have written about his trade policy. ${ }^{1}$ In part, I have focused on the president's reliance on federal statutes, especially those delegating congressional authority to him to take trade actions that rely upon his sole discretionary determinations of national security risks or national emergencies.

To me, trade policy has become one of the most important aspects of foreign policy today. In particular, the legal aspects of global trade relations are of the gravest importance but are trickiest to understand. So far, trade rules have mainly been formulated by lawyers and enforced by judicial tribunals, at both the national and international levels. Lawyers are predominant in the Office of the United States Trade Representative, whose primary functions are to negotiate trade agreements and to conduct trade relations.

We are now at a point where federal courts in the US, the largest economy in the world, have been asked to review the validity of presidential trade actions, specifically the central legality of the broad delegation of congressional trade authority over the last 75 years.

President Trump has, for the first time in US trade history, aggressively redefined its trade policy as "a supporting actor of US national security policy." President Trump's focus on trade imbalances is a part of his broader foreign policy to make America great again. The trade war with China is intended to restrict China's global ambitions. President Trump's actions have involved a broad array of legislation, such as trade sanctions and export controls. They have most prominently involved trade remedy legislation relating to retaliation, safeguards, antidumping and subsidies. President Trump has imposed trade remedies for reasons that are overtly associated with foreign policy: "The manner in which Mr. Trump is wielding America's economic power is unprecedented, as he uses sanctions, tariffs, trade negotiations and export controls interchangeably.", Most astonishing is that President Trump has imposed trade restrictions by relying upon unilateral 
findings of national security risks or the existence of national emergencies. ${ }^{3}$ Swanson and Mozur reported:

President Trump is increasingly blurring the line between America's national and economic security, enabling him to harness powerful tools meant to punish the world's worst global actors and redirect them at nearly every trading partner, including Mexico, Japan, China and Europe. [...] His approach has grown more aggressive over the past two years, culminating in an expansive view of national security that has plunged the United States into an economic war with nearly every trading partner. [...] The Trump administration is facing challenges in court and at the World Trade Organization over its use of national security provisions. ${ }^{4}$

The most recent trade restrictions-who knows which others will arise-concern national security claims as a basis for new tariffs on Mexican goods to induce greater immigration control under the International Emergency Economic Powers Act; ${ }^{5}$ restrictions on Chinese telecom giant Huawei, in the name of national security, under Section 889 of the National Defense Authorization Act (2019); ${ }^{6}$ and tariffs on uranium imports (the administration has at this point declined to do so) and on steel and aluminum, applicable to many of our trading partners and closest allies, under Section 232 of the Trade Expansion Act of $19622^{7}$ President Trump continues to threaten the imposition of new retaliatory tariffs, under Section 301 of the Trade Act of 1974, on German car imports and, most recently, on France for its adoption of new tax legislation aimed at American technology and social media firms. ${ }^{8}$ The administration favors factoring currency manipulation into its subsidy determinations. ${ }^{9}$

\section{Federal Litigation and President Trump's Trade Actions}

Two highly significant federal court actions are already pending against the Trump administration for its trade actions. The first concerns steel imports from many US trade partners, including China. The second, which was recently filed, addresses investment and trade restrictions on Huawei. A third case, concerning the "Mexican immigration tariffs," may well be imminent and will probably involve the US Chamber of Commerce, among others. 
Filed by steel importers, the first case involves the older US Supreme Court case Algonquin (1976), which concerned tariffs and the national security provision (Section 232) of the Trade Expansion Act of 1962. This case was appealed to the Supreme Court, following expedited statutory rules by the steel importers, after an adverse decision by the Court of International Trade. The lower court grudgingly upheld President Trump's steel tariffs under Section 232 because it hesitated to overrule even questionable precedents. However, the Supreme Court denied hearing the case on the expedited basis. ${ }^{10}$ The steel importers have now appealed the lower court decision to the US Court of Appeals for the Federal Circuit.

The second case was recently filed by Huawei. It is asking for summary judgment to address the constitutional prohibition against congressional bills of attainder that single out persons, companies or groups for punishment. ${ }^{11}$ Congress seemingly singled out Huawei by imposing restrictions on it for national security reasons under the new National Defense Authorization Act (Section 889). Huawei's chief legal officer argues that the US Constitution prohibits such acts, saying: "The ban is a quintessential bill of attainder and a violation of due process." $" 12$

The third possible case, of threatening tariffs on Mexican imports, is based upon President Trump's claim that Mexican immigration policy is a threat to the US national security under the International Emergency Economic Powers Act. Even though the administration has recently backed off this threat, a legal action is still possible and would certainly raise the threshold issue, if such a claim is sufficient to satisfy the national security requirement that allows for a valid emergency declaration.

Federal courts review presidential actions, even when they involve foreign policy. This goes back to Curtis Wright (1936), ${ }^{13}$ a 1930's Supreme Court case involving an arms embargo declared by President Roosevelt during the Chaco War in Latin America, and Youngstown (1952), ${ }^{14}$ where the Supreme Court addressed President Truman's seizure of steel mills during the Korean War. In Youngstown, the court clearly stated that the president's powers as commander-in-chief do not include seizing domestic steel mills. Justice Jackson stated that the president is commander-in-chief of the military, not of the nation. ${ }^{15}$ The 1981 Supreme Court case, Dames and Moore ${ }^{16}$ involved President Carter's Iranian hostage agreements. The court upheld those agreements only after a very careful analysis and a finding 
of congressional authorization or implicit congressional acceptance of presidential actions involving the settlement of diplomatic claims. ${ }^{17}$

Presidential actions-even when the president argues that they are not reviewable by courts-are indeed subject to judicial review. This is what is called the rule of law: Congress makes the laws, but all laws and executive actions must comply with the US Constitution to uphold the federal government's structure and to preserve individual rights.

This protection of individual rights is the essence of America's exceptionalism and goes back to the 1791 adoption of the Bill of Rights as amendments to the US Constitution. Under the US Constitution, Congress has exclusive authority over trade. ${ }^{18}$ However, much of this authority has been delegated to the executive branch since the 1930s. So far, Congress has failed to reclaim its trade authority (or its war-making authority).

Congress has the sole constitutional authority to enact new taxes. Congress never intended to abrogate its taxing authority by allowing any president to unilaterally impose new tariffs, which are taxes on the US imports paid by the US firms and consumers. Any foreign retaliatory tariffs hurt everyone, including farmers, importers, consumers and domestic producers. The US government figures indicate that the revenue from Trump's tariffs on USD 250 billion of Chinese imports will not even cover the bailout to US farmers and President Trump is now planning a second bailout for farmers.

President Trump recently announced his intention to impose a new 10 percent tariff on USD 300 billion of additional Chinese imports. Within days China responded with new restrictions on the US agricultural imports and a currency devaluation. The Trump administration immediately designated China a currency manipulator. These actions foreshadow a broadening of the trade war into a currency war. At this point, as a result of the trade war, there has been a significant impact on Chinese investment into the US. For example, there has been a huge 56 percent decline in Chinese buyers of US homes over a recent 12-month period. There has been a drop of 88 percent in 2018, over the prior year, of Chinese foreign direct investment into the US. Expansion of the trade war to include a currency war would certainly result in more economic hardship for the US economy.

In Gundy v. U.S., decided in June 2019, the Supreme Court surprisingly indicated 
that the court may be on the verge of "rejuvenating the nondelegation doctrine." While Gundy v. U.S. ${ }^{20}$ dealt with a nontrade issue, the Supreme Court indicated, in the next appropriate case, that it might well reconsider the fundamental constitutional question of congressional delegation of authority to the executive branch. This would have huge implications for trade cases that might be heard by the court in its next session. A lead editorial in the Wall Street Journal succinctly stated the historical possibility of such a review.

The courts have been reluctant to police this blurring of legislative and executive authority, but that may be changing. In Gundy v. U.S. on Thursday, three of the Supreme Court conservatives showed an appetite for rejuvenating the "nondelegation doctrine," which holds that Congress cannot under the Constitution delegate legislative power to another body. ${ }^{21}$

The editorial goes on to point out that while the three conservative justices dissented, one conservative justice (Justice Brett Kavanaugh) abstained, and one (Justice Samuel Alito), while concurring with the majority, did not support its rationale. ${ }^{22}$ Thus, if a trade case comes along involving congressional delegation of authority to the president, the Supreme Court may very well make a historical decision to uphold Congress' role in foreign trade and limit the president's authority to take broad unilateral action.

\section{Reviving Separation of Powers and the New Federalism}

To me, this possibility of judicial review represents a renewed interest in reviving not only separation of powers but federalism (federal-state relations) in other cases. I wrote, at the early outset of the Trump administration, on the new emerging federalism and newer state and local actions:

This newer federalism promotes global engagement and observation of international rules. This is remarkably different from the older version that supported states' rights and segregation and was primarily based in the South.

Today, we see a rapidly evolving anti-Trump resistance in the widespread movement 
for "sanctuary cities" and the more recent "city-state climate coalition [...] These local actions by cities and states are in opposition to President Trump's national policies relating to immigration enforcement, the rejection of the Paris Climate Accord, and a general contempt for a rules-based international order. ${ }^{23}$

President Trump's reliance on the 1976 National Emergencies Act to declare an 'emergency' and reallocate the US Department of Defense funds to build his wall along the Mexican border only further reflects the extent to which a president's actions can create constitutional battles involving the separation of powers and federalism. ${ }^{24}$ Sixteen states immediately filed cases in federal court and various private legal actions were also filed. ${ }^{25}$ Indeed, the Supreme Court recently "reined in a wayward president" in the case invalidating the inclusion of a citizenship question in the 2020 Census. $^{26}$

A March 2019 study concluded that the federal courts have ruled against the Trump administration at least 63 times over the past two years. Recent cases have only increased Trump's losing number. ${ }^{27}$ Federal district courts have issued 39 nationwide injunctions against executive actions by the Trump administration. To me, President Trump's litigation obsession while in office mirrors his abuse of the domestic legal system, as manifested by his involvement in more than 3,500 cases as a private party and real estate developer. ${ }^{28}$

On the legislative front, the Senate has recently rebuked President Trump's declaration of an emergency under the Arms Export Control Act to sell arms to Saudi Arabia and the United Arab Emirates. Unfortunately, President Trump vetoed this proposed legislation. This congressional action evidences a growing bipartisan consensus that the president's reliance on declarations of emergency and national security rationales is facing growing domestic political resistance. ${ }^{29}$ Edmondson reported:

The Senate voted to block the sale of billions of dollars of munitions to Saudi Arabia and the United Arab Emirates on Thursday, in a sharp and bipartisan rebuke of the Trump administration's attempt to circumvent Congress to allow the exports by declaring an emergency over Iran. ${ }^{30}$ 


\section{WTO Litigation and the US}

Internationally, the legal process is also moving toward examining President Trump's trade actions based upon national security. Numerous cases have been filed against the US in the WTO's dispute-resolution system concerning the administration's reliance on national security. ${ }^{31}$ The administration argues that the WTO cannot review such national security determinations. To use an American legal term, these issues are not justiciable. Unfortunately for the administration, the WTO recently ruled in a case brought by Ukraine against the Russian Federation that national security determinations are indeed reviewable. ${ }^{32}$ This does not bode well for the pending cases against the US. But it should be said that the administration recently seems a bit more willing to settle the WTO cases.

On a related point concerning the US-China litigation in the WTO, litigation has been robust within the WTO between these parties. China has implemented all of the decisions against it, while the US has mostly done the same. The following observations I wrote several years ago remain valid today. ${ }^{33}$

I view U.S.-China litigation in the WTO as validating the strength and critical importance of the WTO and its dispute resolution system. China is now the secondlargest economy in the world. It is expected that disputes increase with trade flows. The strength of the international system is not in the absence of disputes, but in the way that they are resolved. [...] An examination of the cases involving China shows that trade disputes that arise between it and the United States are submitted to the WTO and are resolved, either by diplomatic negotiations in the consultation stage or in the litigation phase. No enforcement actions by either country asking for sanctions have been filed under Article 22 of the Dispute Settlement Understanding. ${ }^{34}$

I suspect and hope this pattern will continue with the Trump administration, despite its recent animosity toward China, the WTO, the dispute-resolution system and the Appellate Body. It is in the American national interest to ensure a rulesbased system with impartial adjudication. 


\section{Prediction}

While it is always dangerous to predict how a federal court or the Supreme Court will decide a case, I predict that the federal courts will uphold the separation of powers in the face of the outrageous and unprecedented onslaught of presidential tariff and trade actions by a president relying on dubious claims of national security and national emergency. Personal gripes can never be a basis for trade policy. My guess is that this judicial action will come from the steel importers' case concerning Section 232. Hopefully, Congress will also be able to claw back some of the trade authority it has delegated to the president. President Trump is obviously determined to disregard domestic and international law and destroy the modern rules-based global trading order. Peter Goodman reported:

President Trump, the leader of the country that built the world trading system, continues to disrupt international commerce as a weapon wielded in pursuit of national aims. [...] The escalating trade war has dealt a potentially grievous blow to the workings of the global commercial system, and especially to its de facto referee, the World Trade Organization. ${ }^{35}$

This global system has been the foundation of the US foreign and national security policy since 1945 and remains so today: "Bretton Woods shaped the post-second world war era not so much because of the specific agreements reached, but because of the commitment to institutionalize co-operation." ${ }^{36}$ The preservation of this system is in the national security interest of the US. 


\section{REFERENCES}

1. See, e.g., S. Malawer, Trump's China Trade Policies: Threats and Constraints, 3 CHInA \& WTO Rev. 109 (2017); Trump Tariff Wars and National Security: A Political and Historical Perspective, 4 ChINA \& WTO Rev. 351 (2018); Pending 232 Litigation and Broader Trade Trends: Will the U.S. Courts Restrict Presidential Authority from Relying Upon National Security?, 5 China \& WTO Rev.183 (2019).

2. S. Fleming, Currency Warrior: Why Trump is Weaponizing the Dollar, FIn. TIMES, July 1, 2019, available at https://www.ft.com/content/5694b0dc-91e7-11e9-aea1-2b1d33ac3271.

3. "These days, the biggest, baddest weapon in the American arsenal isn't a missile, or a tank, or a jet fighter. It is America's economic clout." See G. Seib, U.S. Risks over Using Its Economic Weapons, WALl Sт. J., May 13, 2019, available at https://www.wsj.com/ articles/the-risks-in-overusing-americas-big-economic-weapon-11557750009.

4. A. Swanson \& P. Mozur, Trump Mixes Economic and National Security, Plunging the U.S. into Multiple Fights, N.Y. Times, June 8, 2019, available at https://www.nytimes. com/2019/06/08/business/trump-economy-national-security.html.

5. The International Emergency Economic Powers Act (IEEPA), Title II of Pub. L. 95-223, 91 Stat. 1626, enacted Oct. 28, 1977, available at https://www.law.cornell.edu/uscode/ text/50/chapter-35.

6. John S. McCain National Defense Authorization Act for Fiscal Year 2019, Pub. L. 115232, Aug. 13, 2018, 132 Stat. 1636 available at https://www.law.cornell.edu/topn/john_s_ mccain_national_defense_authorization_act_for_fiscalyear_2019.

7. Trade Expansion Act of 1962, Pub. L. 87-794, Oct. 11, 1962, 76 Stat. 872 (19 U.S.C. 1801 et seq.), available at $\mathrm{https}$ ///www.law.cornell.edu/topn/trade_expansion_act_of_1962.

8. W. Mauldin, French Digital Tax to Face U.S. Prob, WAsh. Post, July 10, 2019, available at https://www.wsj.com/articles/u-s-launches-probe-of-french-digital-tax-11562797720.

9. J. Dorn, Trump's New Currency Plan a Flimsy Attempt to Confront China, The Hill (Feb. 16, 2017), available at https://thehill.com/blogs/pundits-blog/international/319919-trumpsnew-currency-plan-a-flimsy-attempt-to-confront-china.

10. See Challenge to Trump Steel Tariffs Nixed by U.S. Supreme Court, Reuters, June 24, 2019, available at https:/www.reuters.com/article/us-usa-court-steel-idU. S.KCN1TP1PZ.

11. A. Kharpal, Huawei Files New Legal Action as it Tries for a Swift End to its Lawsuit against the U.S. Government, PoLITICO, May 29, 2019, available at https:/www.cnbc.com/ 2019/05/29/huawei-files-motion-for-summary-judgement-in-lawsuit-against-us.html.

12. Liuping Song, Huawei and the U.S. Constitution, Wall St. J., May 28, 2019, available at https://www.wsj.com/articles/huawei-and-the-u-s-constitution-11558989190.

13. United States v. Curtiss-Wright Export Corp., 299 U.S. 304 (1936), available at https:// www.law.cornell.edu/supremecourt/text/299/304. 
14. Youngstown Sheet \& Tube Co. v. Sawyer, 343 U.S. 579 (1952), available at https:// www.law.cornell.edu/supremecourt/text/343/937.

15. Id. at 643-4.

16. Dames \& Moore v. Regan, 453 U.S. 654 (1981), available at https://caselaw.findlaw. com/us-supreme-court/453/654.html.

17. Id.

18. U.S. Const. art. $1, \S 8$, cl. 3.

19. See Justice Gorsuch's dissent in Gundy v. U.S. (Supreme Court No. 17-6086) (June 21, 2019).

20. Gundy v. U.S. (Supreme Court No. 17-6086) (June 21, 2019), available at https://www. law.cornell.edu/supremecourt/text/17-6086.

21. Lead Editorial, Who Makes the Law, Wall St. J., June 21, 2019, available at https:// www.wsj.com/articles/who-makes-the-law-11561157080? $\mathrm{mod}=$ searchresults\&page $=1 \&$ $\operatorname{pos}=7$.

22. Id.

23. S. Malawer, Trump's Foreign Policy and the New Federalism, Richmond TimesDispatch, June 17, 2017, available at https:/www.richmond.com/opinion/their-opinion/ guest-columnists/stuart-s-malawer-trump-s-foreign-policy-and-the-new/article_fff22996d7cb-596f-a1b1-7cb1573e643e.html.

24. P. Baker, Trump Declares a National Emergency, and Provokes a Constitutional Clash, N. Y. Times, Feb. 15, 2019, available at https:/www.nytimes.com/2019/02/15/us/ politics/national-emergency-trump.html.

25. C. Savage \& R. Pear, 16 States Sue to Stop Trump's Use of Emergency Powers to Build Border Wall, N. Y. Times, Feb. 18, 2019, available at https://www.nytimes. com/2019/02/18/us/politics/national-emergency-lawsuits-trump.html?auth=loginemail\&login=email. "The outcome of the challenges to Trump's order could ultimately depend on how much deference courts are willing to give him as president arguing there is a national security issue, said Bobby Chesney, a constitutional law professor at the University of Texas." See M. Berman, F. Barrash \& M. Sacchetti, Courts Face Difficult Question in Battle over Trump Order, WASH. Post, Feb. 19, 2019, available at https:// www.washingtonpost.com/national/trumps-emergency-declaration-to-pay-for-borderwall-faces-a-lengthy-court-battle/2019/02/19/723b61d6-3473-11e9-854a-7a14d7fec96a story.html?utm_term $=.520 \mathrm{c} 729 \mathrm{a} 3 \mathrm{ca} 1$.

26. Editorial, A Win for Democracy, WAsh. Post, July 12, 2019, available at https://www. washingtonpost.com/opinions/our-democratic-institutions-reined-trump-in-on-thecensus/2019/07/12/c1fa16a0-a425-11e9-b732-41a79c2551bf_story.html?utm_term=. ceadee97009a.

27. "Federal judges have ruled against the Trump administration at least 63 times over the past two years, an extraordinary record of legal defeat [...] In case after case, judges 
have rebuked Trump officials for failing to follow the most basic rules of governance for shifting policy, including providing legitimate explanations supported by facts [...]" See F. Barbash \& D. Paul, The Real Reason the Trump Administration is Constantly Losing in Court, WASH. Post, Mar. 20, 2019, available at https://www.washingtonpost. com/world/national-security/the-real-reason-president-trump-is-constantly-losing-incourt/2019/03/19/f5ffb056-33a8-11e9-af5b-b51b7ff322e9_story.html?utm_term=. c9d8303aadb3.

28. J. Byrnes, Trump Involved in 3,500 Law Suits: Report, The Hill (June 1, 2016), available at https://thehill.com/blogs/blog-briefing-room/news/281908-report-trump-involved-in3500-lawsuits.

29. C. Edmondson, Senate Rebukes Trump Bid to Bypass Congress on Arms Sale, N. Y. Times, June 20, 2019, available at https://www.nytimes.com/2019/06/20/us/politics/ saudi-arms-sales.html.

30. Id.

31. Panel Report, United States - Certain Measures on Steel and Aluminum Products, WTO Doc. WT/DS544 (adopted Jan. 25, 2019), available at https://www.wto.org/english/ tratop_e/dispu_e/cases_e/DS544_e.htm.

32. Panel Report, Russia - Measures Concerning Traffic in Transit, WTO Doc. WT/DS512 (adopted Apr. 26, 2019), available at https://www.wto.org/english/tratop_e/dispu_e/ cases_e/ds512_e.htm.

33. S. Malawer, U.S.-China Trade Relations - Litigation in the WTO 2001-2014, 27:1 INT'L

L. Practicum 122 (2014), available at http:/globaltraderelations.net/images/Malawer. U.S._-_CHINA_LITIGATION_IN_THE_WTO_2001-2014_NYSBA,_International_ Law_Practicum_Spring_2014_.pdf.

34. Id. at 126.

35. P. Goodman, Globalization is Moving Past the U.S. and its Vision of the World Order, N. Y. Times, June 19, 2019, available at https://www.nytimes.com/2019/06/19/business/ globalization-us-world-order.html.

36. M. Wolfe, Martin Wolf on Bretton Woods at 75: Global Co-Operation under Threat, FIN. Times, July 10, 2019, available at https://www.ft.com/content/e82a1f48-a185-11e9-a282$2 \mathrm{df} 48 \mathrm{f3} 66 \mathrm{f} 7 \mathrm{~d}$. 